\title{
AMBIENT pH-REGULATED ENZYME SECRETION IN ENDOPHYTIC AND PATHOGENIC ISOLATES OF THE FUNGAL GENUS Colletotrichum
}

\author{
Walter Maccheroni Jr. ${ }^{1 *}$; Welington Luiz Araújo²; João Lúcio Azevedo²,3 \\ ${ }^{1}$ Allelyx Applied Genomics / Techno Park, km. 104, Rod. Anhangüera - 13067-850 - Campinas, SP, Brasil. \\ ${ }_{3}^{2}$ USP/ESALQ - Depto. de Genética, C.P. 83 - 13400-970 - Piracicaba, SP - Brasil. \\ ${ }^{3} U M C$ - Núcleo Integrado de Biotecnologia - Av. Dr. Cândido Xavier de Almeida e Souza, 200 - 08780-911 - Mogi \\ das Cruzes, SP - Brasil. \\ *Corresponding author <walter.maccheroni@alellyx.com.br>
}

\begin{abstract}
In fungi a genetic system ensures that enzymes are secreted mainly at ambient $\mathrm{pH}$ values corresponding to their optima of activity. Although a great deal of information has been obtained concerning this environmental response, there is a lack of studies involving phytopathogenic, endophytic and entomopathogenic fungi as well as different aspects of fungus-host interactions. This study compares in a plate-clearing assays, the effect of ambient $\mathrm{pH}$ in the secretion of amylase, cellulase, lipase, pectinase and protease by endophytic, phytopathogenic, and entomopathogenic isolates belonging to several species of Colletotrichum. All enzymes were secreted in a pH-dependent manner by all isolates. Endophytes and pathogens showed distinct patterns of protease secretion, with optima at alkaline and acid growth conditions, respectively. In liquid medium, a Pi-repressible acid phosphatase of an endophytic isolate responded to ambient $\mathrm{pH}$, having a 14-fold increase in secreted specific activity at acid $\mathrm{pH}$, as compared to alkaline $\mathrm{pH}$. Furthermore, part of a Colletotrichum pac C homologue gene, coding for a transcriptional factor responsible for $\mathrm{pH}$-regulated gene expression, was cloned. Ambient $\mathrm{pH}$ seems to be a general factor controlling enzyme secretion in fungushost interactions through a conserved genetic circuit.

Key words: Glomerella, enzyme secretion, endophytes, pathogenic fungi, pacC
\end{abstract}

\section{SECREÇÃO DE ENZIMAS MEDIADA PELO pH DO AMBIENTE EM ISOLADOS PATOGÊNICOS E ENDOFÍTICOS DO FUNGO Colletotrichum}

\begin{abstract}
RESUMO: Em fungos, um sistema de regulação gênica garante que enzimas sejam secretadas predominantemente em valores de $\mathrm{pH}$ do ambiente próximos aos $\mathrm{pH}$ ótimos de atividade correspondentes. Embora muita informação tenha sido acumulada sobre essa resposta adaptativa, não existem estudos envolvendo fungos fitopatogênicos, endofíticos e entomopatogênicos, bem como sobre outros aspectos relacionados às interações fungo-hospedeiro. No presente trabalho foi comparado, em meio sólido, o efeito do $\mathrm{pH}$ do ambiente na secreção das enzimas amilase, celulase, lipase, pectinase e protease por isolados endofíticos, fitopatogênico e entomopatogênicos pertencentes a diferentes espécies de Colletotrichum. Para todas as enzimas e em todos os isolados, observou-se um padrão de secreção dependente dos valores do $\mathrm{pH}$ do ambiente. Isolados endofíticos e patogênicos apresentaram padrões distintos de secreção de protease, com ótimos em pH de crescimento alcalino e ácido, respectivamente. Em meio líquido, uma fosfatase ácida Pi-repressível, secretada por um isolado endofítico, respondeu ao $\mathrm{pH}$ do ambiente, apresentando um aumento de 14 vezes na sua atividade específica durante o crescimento do fungo em meio ácido, quando comparado a meio alcalino. Além disso, foi clonada parte do gene pac $\mathrm{C}$ de Colletotrichum, o qual codifica um fator de transcrição responsável pela regulação dependente do $\mathrm{pH}$ do ambiente. É plausível a hipótese de que o pH ambiente é um fator de amplo espectro controlando a secreção enzimática durante as interações fungo-hospedeiro por meio de um circuito genético conservado.

Palavras-chave: Glomerella, secreção enzimática, endófitos, fungo patogênico, pacC
\end{abstract}

\section{INTRODUCTION}

During fungal infection a range of hydrolytic enzymes is secreted to help promoting host colonization. Depending of the ecological niche occupied by each fungus, a particular set of enzymes, mainly composed of proteases and carbohydrases, are displayed to degrade specific tissues and scavenge for nutrient resources (Yakoby et al., 2000). Because these enzymes work outside the fungal cell, activity as well as the mechanisms that control synthesis and secretion are under the influence of several environmental factors such as ambient pH (Caddick et al., 1986; Maccheroni Jr. et al., 1995). 
In the saprophyte Aspergillus nidulans, pH-regulated gene expression is under the control of at least seven genes (Maccheroni Jr. et al., 1997; Negrete-Urtasun et al., 1999; Tilburn et al., 1995). Gene pacC codes for a transcriptional factor activated by proteolysis at alkaline growth $\mathrm{pH}$, and is responsible for inducing alkaline-expressed genes (e.g. alkaline protease) and repressing acid-expressed genes (e.g. acid protease). Genes palA, B, C, F, H, and I are components of a transduction pathway that senses ambient $\mathrm{pH}$ and activates the PacC protein. This genetic system seems to be well conserved among fungi (Penãlva \& Arst, 2002), but only very recently a pac C homologue has been identified in a phytopathogen, the filamentous fungus Sclerotinia sclerotiorum (Rollins \& Dickman, 2001).

In phytopathogenic fungi, pectinases are involved in plant cell wall-degradation and are thought to be important determinants of pathogenicity and virulence (Annis \& Goodwin, 1997). Early reports (Hancock, 1966; Sherwood, 1966) demonstrated that secretion of specific pectinolytic activities by phytopathogenic fungi was dependent on the $\mathrm{pH}$ of culture medium. Thus, polygalacturonases (PGs) usually have acid optimum $\mathrm{pH}$ for activity and are produced and secreted preferentially at acid growth conditions, whereas for pectin/pectate lyases (PLs) the opposite occurs. It has been then proposed that the concomitant rise in plant tissue $\mathrm{pH}$ and increase in PL activity and synthesis would account for the switch between a transient biotrophic phase to a highly destructive necrotrophic phase in Colletotrichum lindemuthianum causing bean anthracnose (Bailey et al., 1992). More recent works with Colletotrichum gloeosporioides have shown that ambient $\mathrm{pH}$ regulates PL transcription in vitro (Shih et al., 2000; Yakoby et al., 2000); in planta PL expression in the necrotrophic phase of infection has also been demonstrated (Shih et al., 2000).

Colletotrichum comprises a variety of phytopathogenic species used as models for studies concerning pathogenicity and fungal-plant interaction (Perfect et al., 1999). A few members have also been described as endophytes, establishing asymptomatic plant infections (Araújo et al., 2001; Azevedo et al., 2000; Freeman \& Rodriguez, 1993) and as opportunistic pathogens of insect (Teixeira, 2000) and even man (Ritterband et al., 1997). The aim of this study was to examine the extension of ambient $\mathrm{pH}$ regulation on the in vitro secretion of several enzyme activities by endophytic, phytopathogenic and entomopathogenic isolates of Colletotrichum, and to identify a pacC homologue in the genus.

\section{MATERIAL AND METHODS}

\section{Isolates and growth conditions}

Colletotrichum isolates and respective hosts are listed in Table 1. Endophytes were isolated from surfacesterilized parts of healthy plants and pathogens directly from diseased plant or insect tissues using standard methodologies [all references in Table 1]. Isolates were grown on Potato Dextrose Agar medium and conidia were obtained after 7-14 d. Enzyme assays were carried on solid (1.5\% agar) and liquid minimal medium(containing, $\mathrm{L}^{-1}$ : $\mathrm{KCl}, 0.5 \mathrm{~g} ; \mathrm{MgSO}_{4} .7 \mathrm{H}_{2} \mathrm{O}, 0.5 \mathrm{~g} ; \mathrm{KH}_{2} \mathrm{PO}_{4}, 1.5 \mathrm{~g}$; $\mathrm{Na}_{2} \mathrm{~B}_{4} \mathrm{O}_{7} .10 \mathrm{H}_{2} \mathrm{O}, 0.5 \mathrm{mg}$; $\mathrm{CuSO}_{4} .5 \mathrm{H}_{2} \mathrm{O}, 0.5 \mathrm{mg}$; $\mathrm{FeSO}_{4} .7 \mathrm{H}_{2} \mathrm{O}, \quad 0.5 \mathrm{mg} ; \quad \mathrm{MnSO}_{4} \cdot \mathrm{H}_{2} \mathrm{O}, \quad 0.3 \mathrm{mg}$; $\mathrm{NaMoO}_{4} \cdot 2 \mathrm{H}_{2} \mathrm{O}, 1 \mathrm{mg} ; \mathrm{ZnSO}_{4} \cdot 7 \mathrm{H}_{2} \mathrm{O}, 0.1 \mathrm{~g}$; glucose, $10 \mathrm{~g}$; amonium tartrate, $1 \mathrm{~g}$ ) buffered at $\mathrm{pH} 5.0,6.8$, and 8.0 with $50 \mathrm{mmol} \mathrm{L}{ }^{-1}$ of citrate $\left(\mathrm{Na}^{+}\right)$, MOPS, and Tris- $\mathrm{HCl}$, respectively, and with modifications as specified for each experiment. Growth in liquid media was carried out in a rotary shaker at $200 \mathrm{rpm}$. All growth experiments were performed at $28^{\circ} \mathrm{C}$.

\section{Enzyme secretion assays on solid media}

Enzyme secretion was evaluated in minimal glucose-free medium, supplemented with $0.1 \%$ yeast extract and one of the following carbon sources: $0.5 \%$ dry skim milk Nestlé (protease); 0.5\% CM-cellulose Sigma (cellulase); $0.5 \%$ citrus pectin Sigma (pectinase); $0.2 \%$ soluble corn starch Sigma (amylase); 1\% Tween 20

Table 1 - Wild-type isolates of Colletotrichum and their respective hosts.

\begin{tabular}{|c|c|c|}
\hline Isolate/designation $^{\mathrm{a}}$ & Host $^{\mathrm{b}}$ & Reference \\
\hline \multicolumn{3}{|l|}{ Endophyte } \\
\hline C. musae 7 (E1) & Banana leaves & Maccheroni \& Azevedo, 1998 \\
\hline C. gloeosporioides CAR1 (E2) & Sweet orange leaves & This work \\
\hline C. gloeosporioides CCC (E3) & Sweet orange petals & Teixeira, 2000 \\
\hline \multicolumn{3}{|l|}{ Plant pathogen } \\
\hline C. gloeosporioides CCE (PP1) & Sweet orange petals & Teixeira, 2000 \\
\hline C. acutatum 3KLCC (PP2) & Key lime flower buds & Kuramaeizioka et al., 1997 \\
\hline C. sublineolum (PP3) & Sorghum sp. leaves & Kamida, 1998 \\
\hline \multicolumn{3}{|l|}{ Insect pathogen } \\
\hline C. gloeosporioides $\mathrm{CTAA}_{2}$ (IP1) & Orthezia praelonga & Teixeira, 2000 \\
\hline
\end{tabular}

${ }^{a}$ Designations used in text and Table 2 are in parentheses. ${ }^{b}$ Banana (Musa cavendish); Sweet orange (Citrus sinensis (L.) Osbeck, var. Pera); Key lime (Citrus aurantifolia (L.) Swingle); Orthezia praelonga (Homoptera). 
Amersham (lipase) or $2.4 \%$ purified crab chitin Sigma (chitinase). Chitin and plates for chitinase detection were prepared according to Hankin \& Anagnostakis (1975). Degraded substrate zones were visualized as previously described for protease, amylase, lipase, pectinase, and chitinase (Hankin \& Anagnostakis, 1975) and cellulase (St. Leger et al., 1997). Isolates were point-inoculated onto solid media and allowed to grow for 3-4 d (endophytes) or 5-6 d (pathogens) or until the colony reached at least $2.5 \mathrm{~cm}$ in diameter.

\section{Phosphatase analysis}

Conidia $\left(10^{8}\right)$ were inoculated into $500 \mathrm{~mL}$ Erlenmeyer flasks containing $200 \mathrm{~mL}$ of liquid minimal medium, buffered at $\mathrm{pH} 6.8$ followed by growth for 36 $\mathrm{h}$. The mycelium was harvested, washed with sterile water and further grown in $100 \mathrm{~mL}$ of minimal medium, buffered at different $\mathrm{pH}$ values, for $24 \mathrm{~h}$ under the same described conditions. For phosphatase derepression, further growth was carried out in Pi-free minimal medium $\left(\mathrm{KH}_{2} \mathrm{PO}_{4}\right.$ was replaced with an equimolar concentration of $\mathrm{KCl}$ ). Thereafter, preparation of cell-free extract and determination of phosphatase activities were performed as described previously (Maccheroni \& Azevedo, 1998).

\section{Cloning procedures}

Genomic DNA was extracted from mycelium grown for $48 \mathrm{~h}$ in liquid Potato Dextrose medium according to Andrade-Monteiro et al. (1994). Approximately 200 ng of total DNA were used as template in PCR reactions with degenerated oligonucleotides PAC1 (forward primer; 5'-GTNTGCGARCGNCACGTNGG; consensus amino acid sequence VCERHVG) and PAC2 (reverse primer; 5'-RTCRTCVGCRTGVGTYTTNACRTG; consensus amino acid sequence HVKTHADD). Degeneracy codes are: $\mathrm{R}=\mathrm{A}$ or $\mathrm{G} ; \mathrm{Y}=\mathrm{C}$ or $\mathrm{T} ; \mathrm{V}=\mathrm{A}, \mathrm{C}$ or $\mathrm{G}$, and $\mathrm{N}=$ $\mathrm{A}, \mathrm{C}, \mathrm{G}$ or T. Amplification was performed in a final volume of $25 \mu \mathrm{L}$ containing: assay buffer (Tris- $\mathrm{HCl}$, $\left.70 \mathrm{mmol} \mathrm{L}^{-1}, \mathrm{pH} 9.0\right) ; \mathrm{MgCl}_{2}, 1.5 \mathrm{mmol} \mathrm{L}^{-1} ; 2.5 \mathrm{U}$ of Taq DNA polimerase; $1 \mathrm{mg}$ of each primer and $200 \mathrm{mmol} \mathrm{L}^{-1}$ of each dNTP. PCR was carried out using the following profile: $94^{\circ} \mathrm{C}$ for $4 \mathrm{~min} ; 5$ cycles of $94^{\circ} \mathrm{C}$ for $1 \mathrm{~min}, 38^{\circ} \mathrm{C}$ for $1 \mathrm{~min}$, and $72^{\circ} \mathrm{C}$ for $2 \mathrm{~min} ; 30$ cycles of $94^{\circ} \mathrm{C}$ for 1 $\min , 46^{\circ} \mathrm{C}$ for $1 \mathrm{~min}$, and $72^{\circ} \mathrm{C}$ for $2 \mathrm{~min}$; final extension of $72^{\circ} \mathrm{C}$ for $5 \mathrm{~min}$. PCR products were resolved by agarose gel electrophoresis and stained with ethidium bromide. A fragment of expected size was cut off from the gel, eluted, cloned into pGEM-T vector (Promega), and the recombinant plasmids were electroporated into $E s$ cherichia coli DH5a competent cells. Plasmid DNA from three clones was prepared by routine, alkaline lysis and sequenced on both strands with universal primers (M13 forward and reverse primers) on an ABI 377 automated sequencer using standard ABI protocols.

\section{RESULTS AND DISCUSSION}

\section{Ambient pH-regulated enzyme secretion by endo- phytic and pathogenic isolates of Colletotrichum grown on solid media}

Plate clearing assay has proven to be a method of great simplicity and value in measuring enzyme secretion in fungi (St. Leger et al., 1997) and therefore, was used in the present study. All carbon sources were degraded by all isolates in a pH-dependent manner (Table 2), except for chitin that was not degraded at all (results not shown). Amylase activity was not observed at alkaline $\mathrm{pH}$ and although starch had been degraded at neutral and acid pH, enzyme secretion was discrete and occurred only under the fungal colonies. Pectinase was produced in all growth conditions, but secretion occurred consistently only at acid $\mathrm{pH}$ indicating that pectin degradation is due probably to a polygalacturonase activity. In general, lipase was absent at acid $\mathrm{pH}$ and secreted at neutral and alkaline $\mathrm{pH}$, whereas cellulase was observed in most growth conditions and secreted preferentially at neutral and alkaline $\mathrm{pH}$.

Degradation of protein was observed in all growth conditions with optimal levels at the extremes of the assayed $\mathrm{pH}$ range. In this case, a more distinct pattern was observed among isolates, with endophytes se-

Table 2 - Influence of solid medium $\mathrm{pH}$ on the secretion of five enzyme activities by endophytic and pathogenic isolates of Colletotrichum ${ }^{a}$.

\begin{tabular}{|c|c|c|c|c|c|c|c|c|c|c|c|c|c|c|c|c|}
\hline \multirow[t]{2}{*}{ Isolate } & \multicolumn{4}{|c|}{ Amylase } & \multicolumn{3}{|c|}{ Cellulase } & \multicolumn{3}{|c|}{ Lipase } & \multicolumn{3}{|c|}{ Pectinase } & \multicolumn{3}{|c|}{ Protease } \\
\hline & $\mathrm{pH}$ & 5.0 & 6.8 & 8.0 & 5.0 & 6.8 & 8.0 & 5.0 & 6.8 & 8.0 & 5.0 & 6.8 & 8.0 & 5.0 & 6.8 & 8.0 \\
\hline E1 & & 0.7 & 0.6 & n.d. & 0.8 & 0.9 & 1.0 & n.d. & 1.3 & 2.2 & 1.3 & 1.0 & 1.0 & 1.0 & 1.0 & 1.2 \\
\hline $\mathrm{E} 2$ & & 0.8 & 0.8 & n.d. & n.d. & 1.0 & 1.3 & n.d. & 1.2 & 1.7 & 1.3 & 1.0 & 1.0 & 1.0 & 1.0 & 1.9 \\
\hline E3 & & 0.8 & 0.8 & n.d. & n.d. & 1.0 & 1.5 & n.d. & 1.2 & 1.9 & 1.4 & 1.0 & 1.0 & 1.0 & 1.0 & 1.3 \\
\hline PP1 & & 1.0 & 1.0 & n.d. & 1.0 & 1.1 & 1.3 & n.d. & 1.2 & 1.7 & 1.4 & 1.0 & 1.0 & 1.3 & 1.0 & 1.0 \\
\hline PP2 & & 1.0 & 1.0 & n.d. & n.d. & 1.4 & 1.5 & n.d. & 1.7 & 1.7 & 1.7 & 1.0 & 1.0 & 1.4 & 1.0 & 1.0 \\
\hline PP3 & & 1.0 & 1.0 & n.d. & 1.0 & 1.0 & 1.4 & n.d. & n.d. & 1.5 & 1.3 & 0.7 & n.d. & 1.8 & 0.7 & 1.0 \\
\hline IP1 & & 1.0 & 1.0 & n.d. & 1.0 & 1.2 & 1.3 & n.d. & 1.3 & 2.1 & 1.4 & 1.0 & 1.0 & 1.3 & 1.0 & 1.0 \\
\hline
\end{tabular}

${ }^{a}$ Results are the mean of three independent experiments and represent the enzyme activities expressed as the ratio between the diameters of the degraded zone and the colony. Values $>1$ indicate enzyme secretion into the medium resulting in a degraded zone around the colony. Values $=1$ and $<1$ indicate degraded zones only under the colony. n.d. (not determined) indicates no degraded zone or that it could not be estimated.

Sci. Agric. (Piracicaba, Braz.), v.61, n.3, p.298-302, May/June 2004 
creting more protease activity at alkaline $\mathrm{pH}$ and pathogens at acid $\mathrm{pH}$. Distinct optimum $\mathrm{pH}$-types of protease activities seem to be differentially secreted by the two groups of isolates. Indeed, in isolates of the fungal genus Verticillium, secretion of different profiles of protease activities was also observed and seems to correlate with a specific ecological niche, discriminating between insect and plant pathogens (St. Leger et al., 1997). The fact that the opportunistic entomopathogen IP1 showed similar patterns to those of plant pathogens, regardless of the enzyme activity tested, may lay on the observation that this isolate may be also pathogenic to plants (Teixeira, 2000). Ambient pH-regulated enzyme secretion has already been shown to occur in other fungi occupying different niches and be involved in different aspects of the corresponding interactions. In the ericoid endophytic fungi Hymenoscyphus ericae and Rhodothamus chamaecistus, acid proteases probably involved in nitrogen acquisition from the environment are secreted only at low growth $\mathrm{pH}$ and some of the enzymatic properties seem to correlate with the $\mathrm{pH}$ of the soils of their host plants (Leake \& Read, 1990). In the insect pathogenic fungus Metarhizium anisopliae, alkaline $\mathrm{pH}$ is a physiological signal that triggers the synthesis and secretion of several proteases and a chitinase proposed to be virulence factors in host cuticle penetration (St. Leger et al., 1998; 1999).

\section{Effect of ambient $\mathbf{p H}$ on phosphatase production by C. musae grown in liquid medium}

Four distinct phosphatase activities produced in vitro by endophytic isolates of C. musae have been previously identified by Maccheroni \& Azevedo (1998). Constitutive acid phosphatase, alkaline phosphatase, and phosphodiesterase activities were observed only inside the cells and thus, are not expected to be deeply influenced by ambient pH (Caddick et al., 1986). The only extracel- lular activity observed was a Pi-repressible acid phosphatase that may respond to variations in ambient $\mathrm{pH}$. To assess those expectations, the effect of ambient $\mathrm{pH}$ on the production of these four enzyme activities was carried out under nutritional sufficiency and Pi-starvation conditions. Only the Pi-repressible acid phosphatase markedly responds to ambient $\mathrm{pH}$, having a 14-fold increase in secreted activity at acid $\mathrm{pH}$ as compared to alkaline $\mathrm{pH}$ (Table 3).

\section{Identification of a pac $\mathrm{C}$ homologue in $\boldsymbol{C}$. sublineolum}

A PCR strategy was used to identify a pacC homologue in Colletotrichum. The PacC sequences from $A$. nidulans, A. niger, and $P$. chrysogenum (GeneBank accession numbers S54308, S63587, and AAC36492, respectively) were aligned and a highly conserved amino acid block, comprising the DNA binding motif (Denison, 2000), was chosen to designate a pair of degenerated primers. These primers were then used to amplify genomic DNA from all Colletotrichum isolates in Table 1. Except for isolates E1 and E3, amplification from all others yielded a DNA fragment of expected size. Isolate PP3 showed the most distinct band against the amplified background and therefore, it was further cloned and sequenced. A 213 bp nucleotide sequence (GeneBank accession number AF260325) coding for a putative polypeptide $100 \%$ similar to the PacC proteins of $\mathrm{As}$ pergillus was revealed (Figure 1) and strongly suggests the existence of a pac C homologue in Colletotrichum. In conclusion ambient $\mathrm{pH}$ may be a general factor controlling enzyme secretion in Colletotrichum. Furthermore, the identification of a pac $\mathrm{C}$ homologue in $C$. sublineolum reinforces the idea of a conserved genetic circuit widespread in nature and being responsible, at least in part, for $\mathrm{pH}$-regulated gene expression that takes place in fungus-host interactions (Rollins \& Dickman, 2001).

Table 3 - Influence of liquid medium $\mathrm{pH}$ on the synthesis and secretion of phosphatases by the E1 endophyte of C. musae.

\begin{tabular}{|c|c|c|c|c|c|c|c|c|c|}
\hline \multirow{4}{*}{ Enzyme activity } & \multicolumn{9}{|c|}{ Growth condition $^{\mathrm{a}}$} \\
\hline & \multicolumn{3}{|c|}{ pH 5.0} & \multicolumn{3}{|c|}{ pH 6.8} & \multicolumn{3}{|c|}{ pH 8.0} \\
\hline & \multirow{2}{*}{$\begin{array}{l}+\mathrm{Pi} \\
\mathrm{CE}\end{array}$} & \multicolumn{2}{|c|}{$\mathrm{Pi}$} & \multirow{2}{*}{$\begin{array}{l}+\mathrm{Pi} \\
\mathrm{CE}\end{array}$} & \multicolumn{2}{|c|}{$\mathrm{Pi}$} & \multirow{2}{*}{$\begin{array}{l}+\mathrm{Pi} \\
\mathrm{CE}\end{array}$} & \multicolumn{2}{|c|}{$\mathrm{Pi}$} \\
\hline & & $\mathrm{CE}$ & $\mathrm{CM}$ & & $\mathrm{CE}$ & $\mathrm{CM}$ & & $\mathrm{CE}$ & $\mathrm{CM}$ \\
\hline Acid phosphatase & $4.6 \pm 0.6^{c}$ & $8.2 \pm 0.4$ & n.d. & $7.9 \pm 0.2$ & $7.1 \pm 0.6$ & n.d. & $6.1 \pm 0.7$ & $4.4 \pm 0.3$ & n.d. \\
\hline $\begin{array}{l}\text { Alkaline } \\
\text { phosphatase }\end{array}$ & $1.1 \pm 0.3$ & $0.8 \pm 0.2$ & n.d. & $1.4 \pm 0.1$ & $1.3 \pm 0.1$ & n.d. & $1.6 \pm 0.3$ & $2.0 \pm 0.1$ & n.d. \\
\hline Phosphodiesterase & $1.8 \pm 0.2$ & $6.5 \pm 0.8$ & n.d. & $3.6 \pm 0.5$ & $8.0 \pm 0.7$ & n.d. & $4.9 \pm 0.2$ & $8.9 \pm 0.3$ & n.d. \\
\hline $\begin{array}{l}\text { Pi-repressible acid } \\
\text { phos. }\end{array}$ & $2.4 \pm 0.2$ & $6.0 \pm 0.3$ & $28.4 \pm 5.2$ & $3.6 \pm 0.1$ & $4.4 \pm 0.2$ & $6.2 \pm 0.5$ & $2.9 \pm 0.4$ & $2.8 \pm 0.2$ & $2.0 \pm 0.3$ \\
\hline
\end{tabular}




$\begin{array}{lrlll}\text { An } & 104 & \text { RKSTNNLNLTCQWGSCRTTTVKRDH I TSH IRVHVP LKP HKCDFCGKAFKRP QDLKK } & 159 \\ \text { Ag } & 98 & \text { RKSTNNLNLTCQWGSCRTTTVKRDHI TSH IRVHVP LKP HKCDFCGKAFKRP QDLKK } & 153 \\ \text { CS } & 1 & \text { RKSTNNLNLTCQWGSCRTTTVKRDHI TSH IRVHVP LKP HKCDFCGKAFKRPQDLKK } & 56 \\ \text { PC } & 86 & \text { RKSTNNLNLTCQWGTCNTTTVKRDHITSH IRVHVP LKP HKCDFCGKAFKRPQDLKK } & 141 \\ \text { Ss } & 73 & \text { RKSTNNLNLTCGWNSCRTTTVKRDHI TSH IRVHVP LKP HKCEFCGKAFKRPQDLKK } & 128\end{array}$

Figure 1 - Alignment of the partial amino acid sequence of PacC from C. sublineolum (Cs) and the corresponding protein regions of A. nidulans (An), A. niger (Ag), P. chrysogenum $(\mathrm{Pc})$ and S. sclerotiorum (Ss). Primer sequences were not used for translation of the $S$. sclerotiorum protein. Numbers on the sides of the alignment refer to the original position of amino acids in the respective proteins. Identical and similar residues are shown on black and grey backgrounds, respectively. Sequence alignment was performed using the Clustal W program (http://www.hgsc.bcm.tmc.edu/SearchLauncher).

\section{ACKNOWLEDGEMENTS}

This research was funded by CNPq and FAPESP. We thank FAPESP (Proc. nํ. 00/010699-1) for the fellowship to W.L.A and C. I. Aguilar-Vildoso, M. A. Teixeira and H. M. Kamida for generously providing us with fungal isolates.

\section{REFERENCES}

ANDRADE-MONTEIRO, C.; MACCHERONI JR., W.; ROSSI, A.; MARTINEZ-ROSSI, N.M. A simplified method for the isolation of high molecular weight DNA from Aspergillus nidulans. Brazilian Journal of Genetics, v.17, p.447-448, 1994.

ANNIS, S.L.; GOODWIN, P.H. Recent advances in the molecular genetics of plant cell wall-degrading enzymes produced by plant pathogenic fungi. European Journal of Plant Pathology, v.103, p.1-14, 1997.

ARAÚJO, W.L.; SARIDAKIS H.O.; BARROSO, P.A.V.; AGUILARVILDOSO, C.I.; AZEVEDO J.L. Variability and interactions between endophytic bacteria and fungi isolated from leaf tissues of citrus rootstocks. Canadian Journal of Microbiology, v.47, p.229-236, 2001.

AZEVEDO, J.L.; MACCHERONI JR., W.; PEREIRA, J.O.; ARAÚJO, W.L. Endophytic microorganisms: a review on insect control and recent advances on tropical plants. EJB: Electronic Journal of Biotechnology, v.3, 2000. http://www.ejb.org/content/vol3/issue1/full/4/index.html. Acesso em: 15 maio 2003.

BAILEY, J.A.; O'CONNELL, R.J.; PRING, R.J.; NASH, C. Infection strategies of Colletotrichum. In: BAILEY, J.A.; JEGER, M.J. (Ed.) Colletotrichum: Biology, pathology and control. Wallingford: $\mathrm{CAB}$ International, 1992. p.88-120.

CADDICK, M.X.; BROWNLEE, A.G.; ARST JR., H.N. Regulation of gene expression by $\mathrm{pH}$ of the growth medium in Aspergillus nidulans. Molecular and General Genetics, v.203, p.346-353, 1986.

DENISON, S.H. pH regulation of gene expression in fungi.Fungal Genetics Biology, v.29, p.61-71, 2000.

FREEMAN, S.; RODRIGUEZ, R.J. Genetic conversion of a fungal plant pathogen to a nonpathogenic, endophytic mutualist. Science, v.260, p.75-78, 1993.

HANCOCK, J.G. Pectate lyase production by Colletotrichum trifolii in relation to changes in pH. Phytopathology, v.56, p.1112-1113, 1966.

HANKIN L.; ANAGNOSTAKIS, S.L. The use of solid media for detection of enzyme production by fungi. Mycologia, v.67, p.597-607, 1975.

KAMIDA, H.M. Influence of Saccharomyces cerevisiae in gene expression of the enzyme phenylalanine amonnia-lyase and in the phenolic metabolism of sorghum tissues. Piracicaba: USP/ESALQ, 1998. 59p. (Dissertação - Mestrado).

KURAMAEIZIOKA, E.E.; LOPES, C.R.; SOUZA, N.L.; MACHADO, M.A. Morphological and molecular characterisation of Colletotrichum spp. from citrus orchards affected by postbloom fruit drop in Brazil. European Journal of Plant Pathology, v.103, p.323-329, 1997.

LEAKE, J.R.; READ, D.J. Proteinase activity in mycorrhizal fungi. I. The effect of extracellular $\mathrm{pH}$ on the production and activity of proteinase by ericoid endophytes from soils of contrasted $\mathrm{pH}$. New Phytologist, v.115, p.243-250, 1990.

MACCHERONI JR., W.; AZEVEDO, J.L. Synthesis and secretion of phosphatases by endophytic isolates of Colletotrichum musae grown under conditions of nutritional starvation. Journal of General and Applied Microbiology, v.44, p.381-387, 1998.
MACCHERONI JR., W.; MARTINEZ-ROSSI, N.M.; ROSSI, A. Does gene palB regulate the transcription or the post-translational modification of Pi-repressible phosphatases of Aspergillus nidulans. Brazilian Journal of Medical Biology Research, v.28, p.31-38, 1995.

MACCHERONI JR., W.; MAY, G.S.; MARTINEZ-ROSSI, N.M.; ROSSI, A. The sequence of palF, an environmental $\mathrm{pH}$ response gene in Aspergillus nidulans. Gene, v.194, p.163-167, 1997.

NEGRETE-URTASUN, S.; REITER, E.; DIEZ, E.; TILBURN, J.; ESPESO, E.A.; PEÑALVA, M.A.; ARST JR., H.N. Ambient pH signal transduction pathway in Aspergillus: completion of gene characterization. Molecular Microbiology, v.33, p.994-1003, 1999.

PENÃLVA, M.A.; ARST, H.N.JR. Regulation of gene expression by ambient $\mathrm{pH}$ in filamentous fungi and yeasts. Microbiology and Molecular Biology Reviews, v.66, p.426-446, 2002.

PERFECT, S.E.; HUGHES, H.B.; O'CONNELL, R.J.; GREEN, J.R. Colletotrichum: A model genus for studies on pathology and fungalplant interactions. Fungal Genetics and Biology, v.27, p.186-198, 1999.

RITTERBAND, D.C.; SHAH, M.; SEEDOR, J.A. Colletotrichum graminicola: A new corneal pathogen. Cornea, v.16, p.362-364, 1997.

ROLLINS J.A.; DICKMAN, M.B. pH signaling in Sclerotinia sclerotiorum: identification of a pacC/RIM1 homolog. Applied and Environmental Microbiology, v.67, p.75-81, 2001.

SHERWOOD, R.T. Pectin lyase and polygalacturonase production by Rhizoctonia solani and other fungi. Phytopathology, v.56, p.279-286, 1966.

SHIH, J.; WEI, Y.; GOODWIN, P.H. A comparison of the pectate lyases genes, pel-1 and pel-2, of Colletotrichum gloeosporioides f.sp. malvae and the relationship between their expression in culture and during necrotrophic infection. Gene, v.243, p.139-150, 2000.

ST. LEGER, R.J.; JOSHI, L.; ROBERTS, D.W. Adaptation of proteases and carbohydrases of saprophytic, phytopathogenic and entomopathogenic fungi to the requirements of their ecological niches. Microbiology, v.143, p.1983-1992, 1997.

ST. LEGER, R.J.; JOSHI, L.; ROBERTS, D.W. Ambient pH is a major determinant in the expression of cuticle-degrading enzymes and hydrophobin by Metarhizium anisopliae. Applied and Environmental Microbiology, v.64, p.709-713, 1998.

ST. LEGER, R.J.; NELSON, J.O.; SCREEN, S.E. The entomopathogenic fungus Metarhizium anisopliae alters ambient $\mathrm{pH}$, allowing extracellular protease production and activity. Microbiology, v.145, p.2691-2699, 1999.

TEIXEIRA, M.A. Phytopathogenicity of Colletotrichum gloeosporioides, biocontrol agent of Orthezia praelonga. Botucatu: UNESP/FCA, 2000. 82p. (Dissertação - Mestrado).

TILBURN, J.; SARKAR, S.; WIDDICK, D.A.; ESPESO, E.A.; OREJAS, M.; MUNGROO, J.; PEÑALVA, M.A.; ARST JR., H.N. The Aspergillus PacC zinc finger transcription factor mediates regulation of both acid and alkaline expressed genes by ambient pH. EMBO Journal, v.14, p.779-790, 1995.

YAKOBY, N.; KOBILER, I.; DINOOR, A.; PRUSKY, D. pH regulation of pectate lyase secretion modulates the attack of Colletotrichum gloeosporioides on avocado fruits. Applied and Environmental Microbiology, v.66, p.1026-1030, 2000.

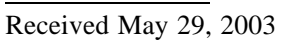

Accepted March 05, 2004

Sci. Agric. (Piracicaba, Braz.), v.61, n.3, p.298-302, May/June 2004 